Article

\title{
Pyramiding Bacterial Blight Resistance Genes in Tainung82 for Broad-Spectrum Resistance Using Marker-Assisted Selection
}

\author{
Yu-Chia Hsu ${ }^{1}$, Chih-Hao Chiu ${ }^{2}$, Ruishen Yap ${ }^{1}$, Yu-Chien Tseng ${ }^{1}\left(\mathbb{D}\right.$ and Yong-Pei $\mathrm{Wu}^{2, *}$ \\ 1 Department of Agronomy, National Chiayi University, Chiayi 60004, Taiwan; \\ hsuychia@mail.ncyu.edu.tw (Y.-C.H.); ruishen0506@gmail.com (R.Y.); yct@mail.ncyu.edu.tw (Y.-C.T.) \\ 2 Department of Agronomy, Chiayi Agricultural Experiment Station, Taiwan Agricultural Research Institute, \\ Chiayi 60014, Taiwan; robinchiu3310@gmail.com \\ * Correspondence: wuypei@dns.caes.gov.tw; Tel.: +886-5-2753156
}

Received: 3 December 2019; Accepted: 12 February 2020; Published: 14 February 2020

\begin{abstract}
Tainung82 (TNG82) is one of the most popular japonica varieties in Taiwan due to its relatively high yield and grain quality, however, TNG82 is susceptible to bacterial blight (BB) disease. The most economical and eco-friendly way to control BB disease in japonica is through the utilization of varieties that are resistant to the disease. In order to improve TNG82's resistance to $\mathrm{BB}$ disease, five bacterial blight resistance genes (Xa4, xa5, Xa7, $x a 13$ and Xa21) were derived from a donor parent, IRBB66 and transferred into TNG82 via marker-assisted backcrossing breeding. Five BB-resistant gene-linked markers were integrated into the backcross breeding program in order to identify individuals possessing the five identified BB-resistant genes (Xa4, $x a 5, \mathrm{Xa7}, x a 13$ and $\mathrm{Xa21}$ ). The polymorphic markers between the donor and recurrent parent were used for background selection. Plants having maximum contribution from the recurrent parent genome were selected in each generation and crossed with the recipient parent. Selected $\mathrm{BC}_{3} \mathrm{~F}_{1}$ plants were selfed in order to generate homozygous $\mathrm{BC}_{3} \mathrm{~F}_{2}$ plants. Nine pyramided plants, possessing all five BB-resistant genes, were obtained. These individuals displayed a high level of resistance against the BB strain, XF89-b. Different BB gene pyramiding lines were also inoculated against the BB pathogen, resulting in more than three gene pyramided lines that exhibited high levels of resistance. The five identified BB gene pyramided lines exhibited yield levels and other desirable agronomic traits, including grain quality and palatability, consistent with TNG82. Bacterial blight-resistant lines possessing the five identified BB genes exhibited not only higher levels of resistance to the disease, but also greater yield levels and grain quality. Pyramiding multiple genes with potential characteristics into a single genotype through marker-assisted selection can improve the efficiency of generating new crop varieties exhibiting disease resistance, as well as other desirable traits.
\end{abstract}

Keywords: rice; pyramiding; bacterial blight; marker-assisted selection; foreground selection; background selection

\section{Introduction}

As a carbohydrate-rich staple of more than half the world's diet, rice (Oryza sativa L.) is one of the most important food crops on the planet. The Food and Agriculture Organization of the United Nations (FAO) estimates that by 2050, overall global agricultural production may need to be increased by up to $70 \%$ to meet the dietary requirements of the world's projected population of nine billion [1]. In order to satisfy the demand corresponding to the FAO's projected population in 2050, global rice production would have to increase by nearly $42 \%$ over present-day levels [2]. Bacterial blight (BB) caused by Xanthomonas oryzae pv. oryzae (Xoo) is a disease that poses one of the greatest threats to rice 
production worldwide. In Asia, BB has proven to be capable of reducing crop yields by as much as $50 \%$ [3] to $80 \%$ [4]. The disease, being systemic, affects the photosynthetic areas of plants, which results in a drastically lower yield. Although BB can be managed through the use of fungicides, enhancing the genetic resistance in rice is the most effective and ecological method of overcoming the threat posed by the disease.

To date, 42 BB resistance genes have been identified from diverse sources, of which Xa4, $x a 5$, $\mathrm{X} a 7, x a 13$ and $\mathrm{X} a 21$ are most frequently utilized in $\mathrm{BB}$ resistance breeding programs [5-7]. Although the $\mathrm{BB}$ resistance genes $x a 5$ and $x a 13$ are recessive in nature, abundant molecular marker resources allow for molecular marker-assisted breeding [8-11]. The $x a 5$ gene encodes a mutated gamma subunit of basal transcription factor IIA 5 (TFIIA $\gamma 5$ ), and along with the dominant resistance gene $\mathrm{X} a 7$, has shown strong resistance to a virulent BB strain, Z-173, in China [11,12]. Another broad-spectrum recessive gene, $x a 13$, was correlated with a plasma membrane protein conferring recessive resistance to PXO99 [13]. Xa21, which encodes a leucine-rich repeat (LRR) receptor kinase-type gene, was identified from $O$. longistaminata; it is one of the most effective genes utilized in breeding programs designed to enhance the BB resistance of rice cultivars $[8,14]$.

Conventional backcross breeding embedded with marker-assisted selection (MAS) has been successfully employed in developing crop varieties exhibiting agronomically important traits. The utility of MAS in pyramiding several resistance genes to develop a variety possessing broad-spectrum durable resistance has been successfully demonstrated against numerous pathotypes $[6,15,16]$; Jalmagna, a high-yield, deep-water rice variety, was improved for BB resistance by pyramiding three resistance genes, $x a 5+x a 13+$ Xa21 [6]; a Korean elite japonica variety, Mangeumbyeo, improved with the introgression of the Xa4 $+x a 5+X a 21$ genes, which were shown to possess a wide range of resistance to $\mathrm{BB}[16]$. Recently, $x a 5, x a 13$ and $\mathrm{Xa21}$ genes were introgressed into the hybrid rice maintainer lines $\mathrm{CO} 2 \mathrm{~B}, \mathrm{BO} 23 \mathrm{~B}$ and $\mathrm{CO} 24 \mathrm{~B}$ through MAS, which can form the basis to develop new, widely adaptable heterotic hybrids possessing resistance against the destructive diseases to which rice is vulnerable [17]. In addition, there have been several examples of MAS being utilized to successfully incorporate different genes which provide higher resistance to various biotic and abiotic stresses (for example, the pyramiding of QTLs of submergence tolerance (Sub1A), leaf/neck blast ( $q B L 1$ and $q B L 11)$, brown planthopper (Bph3) and BB ( $x a 5$ and Xa21) in high-yielding and aromatic rice variety 'Pink3' [18]).

According to the annual report of the Council of Agriculture, of the 271,000 hectares of rice paddy fields in Taiwan, approximately $7 \%$ are affected by BB per year. Most Taiwanese japonica rice cultivars lack BB resistance genes [10], resulting in significant yield loss in fields severely infected by the disease. Pyramiding multiple $R$ genes by MAS provides a rapid and precise way to develop a variety with wide-spectrum and durable resistance [19]. A set of 17 near-isogenic lines (NILs) in IR24 background, having single or two to four pyramided $X a$ genes, were included in the panel to serve as controls of known disease reactions [20]. IRBB66, carrying Xa4, xa5, Xa7, xa13 and Xa21, in an indica rice IR24 genetic background, conferred strong resistance to races of BB. In the present study, five BB resistance genes were introgressed from IRBB66 into an elite japonica variety, 'Tainung82' (TNG82), using marker-assisted backcrossing (MAB) and marker-assisted background analysis of selected backcross progenies using SSR markers. The aims of this study were to (i) develop five gene pyramiding lines using $\mathrm{MAB}$, (ii) evaluate the effects of BB-resistant lines carrying different $\mathrm{R}$ genes after inoculation with $\mathrm{BB}$ strain, (iii) select individuals possessing agronomic traits and grain quality performance from the resulting BB-resistant lines. The development of BB-resistant lines with more than three genes pyramided has a promising future in molecular breeding of durable BB-resistant rice cultivars. 


\section{Results}

\subsection{Development of $\mathrm{BC}_{3} \mathrm{~F}_{4}$ Pyramided Lines Using Marker-Assisted Breeding}

Tainung82 is one of the most widely cultured elite japonica varieties in Taiwan, but it exhibits a high susceptibility to bacterial blight disease. In order to develop a BB-resistant japonica cultivar, TNG82 was used as the recurrent parent to backcross with IRBB66 for three generations, and then self-crossed to produce a $\mathrm{BC}_{3} \mathrm{~F}_{4}$ population. The polymorphism was detected between donor parent IRBB66 and recurrent parent TNG82 with the markers Xa4F/4R, RM604F/604R, Xa7F/7-1R/7-2R, Xa13F/13R and $\mathrm{Xa21F} / 21 \mathrm{R}$ for $\mathrm{Xa4}, x a 5, \mathrm{Xa7}, x a 13$ and $\mathrm{Xa21}$, respectively. In addition, the parents were screened with 216 rice microsatellite markers, of which 143 were polymorphic and 117 were used for background selection (Figure S1). The breeding scheme using molecular markers for the selection of the five BB-resistant genes is shown in Figure 1. During the breeding procedure, functional marker selection was practiced from the $F_{1}$ generation until the $B_{3} F_{2}$ generation. The plants possessing all five resistance genes were selected in each stage, of which only two progenies were advanced to the next generation. A total of two plants having all five BB resistance genes (Xa4, xa5, Xa7, xa13 and Xa21) were screened from $960 \mathrm{~F}_{2}$ plants and confirmed by lined molecular markers [10]. The two $\mathrm{F}_{2}$ plants were backcrossed to TNG82. A total of 53 of $147 \mathrm{BC}_{1} \mathrm{~F}_{1}$ plants containing different $\mathrm{BB}$ resistance genes were selected by MAS. The percentages of recurrent parent genome (\%RG) of $\mathrm{BC}_{1} \mathrm{~F}_{1}$ ranged from $60 \%$ to $85 \%$, with an average of $73.8 \%$ (Figure 2 ). Ten $\mathrm{BC}_{1} \mathrm{~F}_{1}$ plants containing both the five $\mathrm{BB}$ resistance genes, as well as a high \%RPG (average of $81.7 \%$ ), were used for further backcrossing with TNG82.

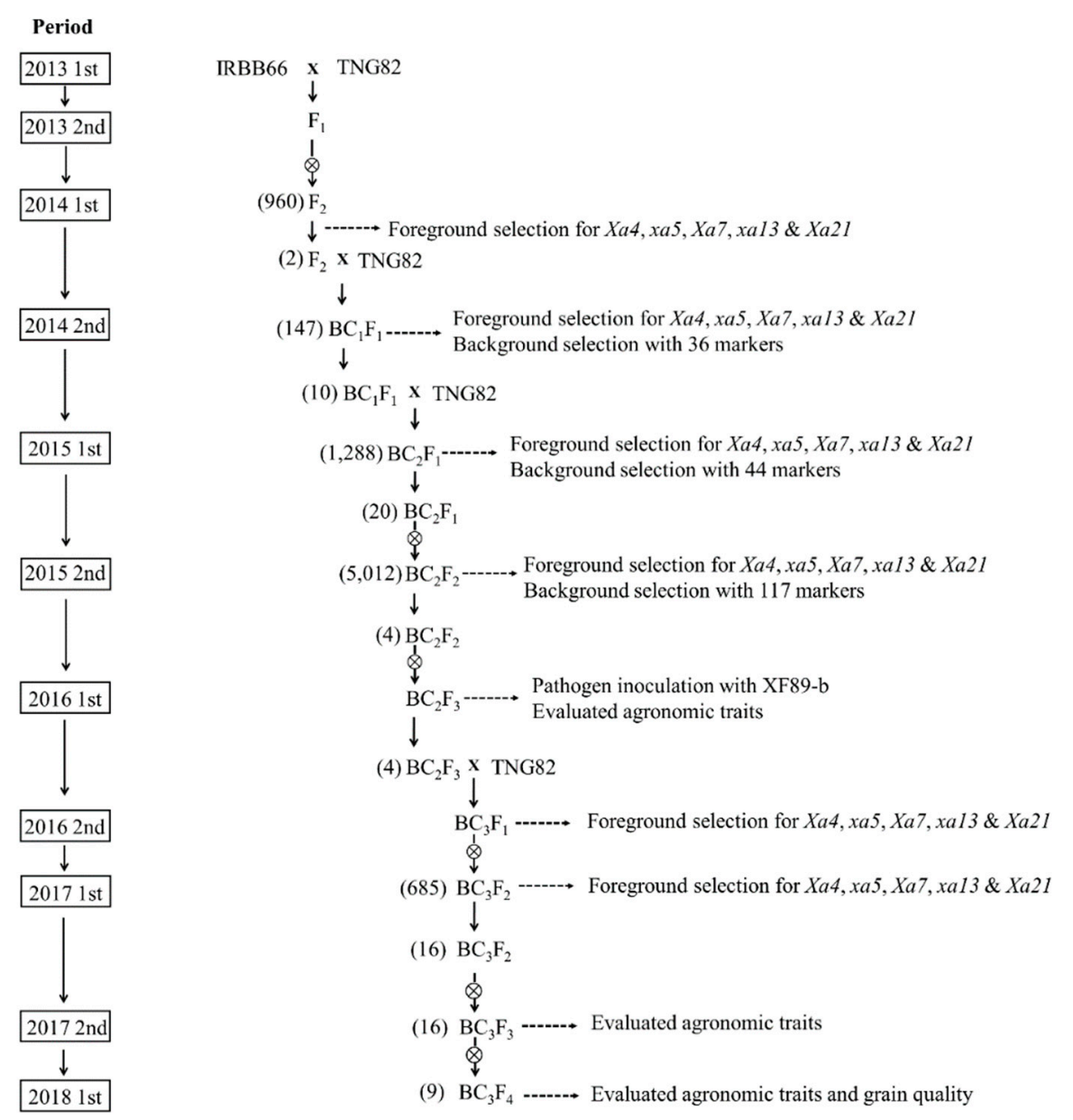

Figure 1. Schematic diagram for pyramiding bacterial blight resistance genes into Taiwanese japonica rice cultivar, TNG82, using marker-assisted selection and number of plants selected in every generation. 


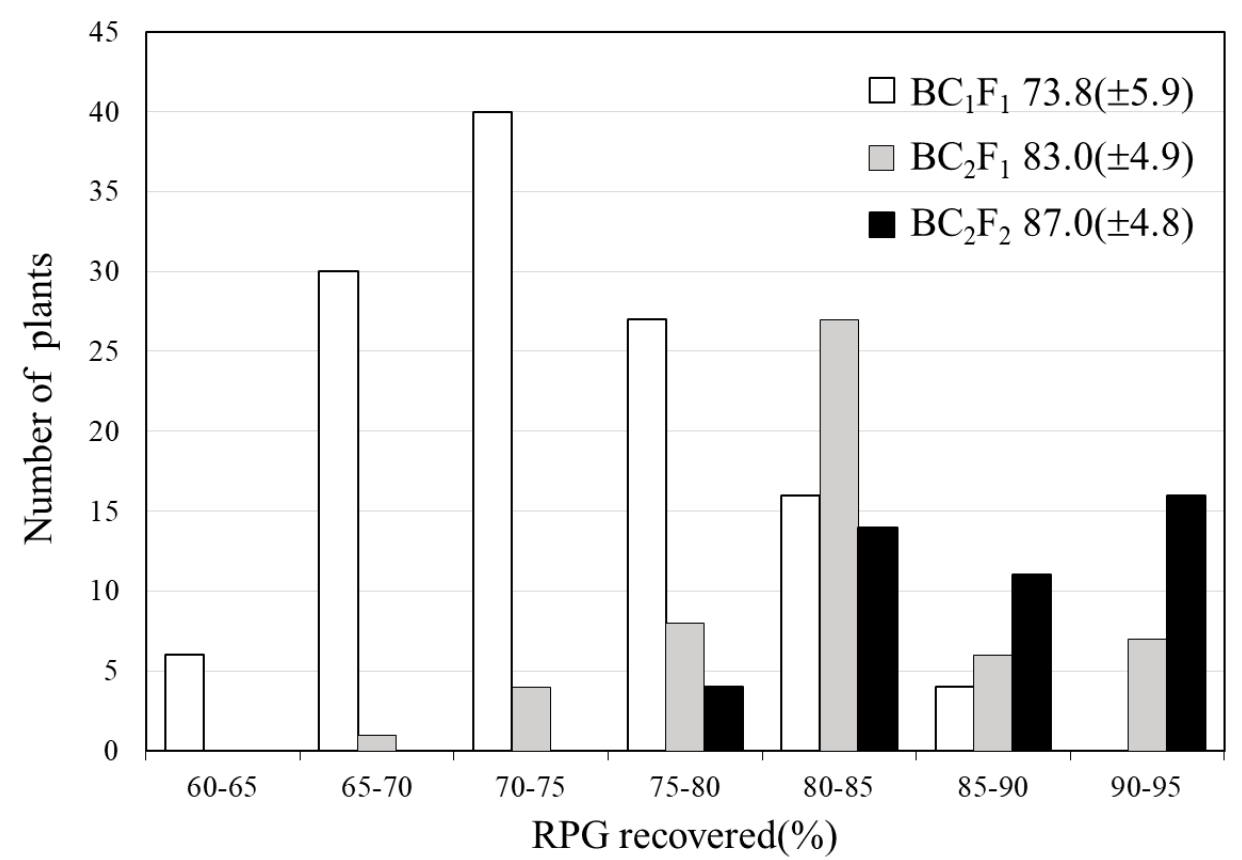

Figure 2. The frequency distribution of recurrent parent genome (RPG) recovered rate using marker-assisted backcrossing in $\mathrm{BC}_{1} \mathrm{~F}_{1}, \mathrm{BC}_{2} \mathrm{~F}_{1}$ and $\mathrm{BC}_{2} \mathrm{~F}_{2}$ populations derived from the backcross of IRBB66/TNG82. The numbers inside the right side of frame indicate the mean values (SD) of RPG recovered.

A total of 50 of $1228 \mathrm{BC}_{2} \mathrm{~F}_{1}$ plants containing different $\mathrm{BB}$ resistance genes possessed the recurrent genome content of TNG82, ranging from $72 \%$ to $94 \%$, with an average of $83 \%$ (Figure 2). The 20 selected $\mathrm{BC}_{2} \mathrm{~F}_{1}$ plants, heterozygous for all five $\mathrm{BB}$ resistance genes and possessing a high \%RPG (average of $87.3 \%$ ), were selfed to obtain the $\mathrm{BC}_{2} \mathrm{~F}_{2}$ population. The plants homologous for all five target genes were segregated with a Mendelian pattern (homozygous preference genotype $=1 / 4^{\mathrm{n}}$ ). The four $\mathrm{BC}_{2} \mathrm{~F}_{2}$ plants carrying five positive homozygous alleles of the donor genes, including $\mathrm{X} a 4, x a 5, \mathrm{Xa}$, $x a 13$ and $\mathrm{X} a 21$, were screened from $5012 \mathrm{BC}_{2} \mathrm{~F}_{2}$ plants. Four $\mathrm{BC}_{2} \mathrm{~F}_{2}$ plants showed recurrent genome content of TNG82 with \%RPG of $92.05 \%$ (29), 84.3\% (18), 83.1\% (5) and $79.4 \%$ (43), with an average of $84.71 \%$ (Table S1). In the $\mathrm{BC}_{2} \mathrm{~F}_{3}$ generation, 17 plants containing different $\mathrm{BB}$ resistance genes were used to confirm resistance reaction by inoculation with $\mathrm{Xoo}$ isolate $\mathrm{XF} 89-\mathrm{b}$ and evaluated for agronomic performance. Four $\mathrm{BC}_{2} \mathrm{~F}_{3}$ plants with the five $\mathrm{BB}$ resistance genes were backcrossed to TNG82. In the $\mathrm{BC}_{3} \mathrm{~F}_{2}$ generation, 16 of 685 plants containing the five $\mathrm{BB}$ resistance genes were identified and grown as $\mathrm{BC}_{3} \mathrm{~F}_{3}$. These 16 five-gene-pyramided genotypes were selfed and evaluated for agronomic performance. The nine $\mathrm{BC}_{3} \mathrm{~F}_{4}$ lines containing five $\mathrm{BB}$ resistance genes, $\mathrm{X} a 4, x a 5, \mathrm{X} a 7, x a 13$ and $\mathrm{Xa21}$ (Figure 3) were selected and evaluated for agronomic performance in the field, as well as analyzed for grain quality. 


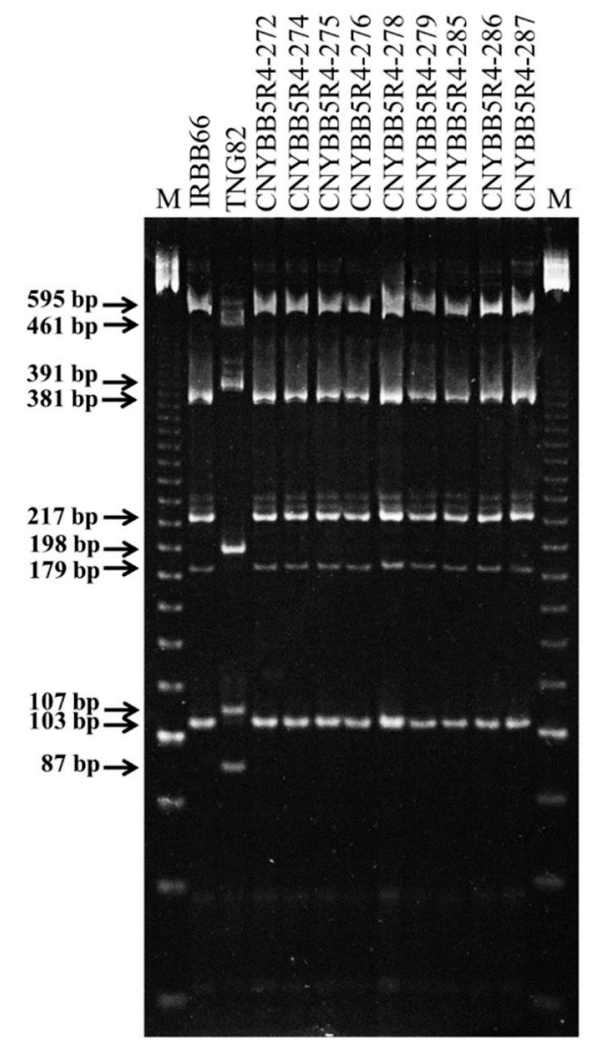

Figure 3. Multiplex PCR amplification of five bacterial blight resistance genes, $\mathrm{X} a 4, x a 5, \mathrm{X} a 7, x a 13$ and Xa21. The five expected band sizes of 217, 106, 179, 381 and $595 \mathrm{bp}$, correlated with Xa4, xa5, Xa7, xa13 and Xa21, respectively, were amplified in IRBB66 and nine five-gene-pyramided lines using multiplex PCR. P1:IRBB66, P2:TNG82. DNA products were separated by $6 \%$ polyacrylamide gel in $0.5 \times \mathrm{TBE}$ at $100 \mathrm{v}$ for $60 \mathrm{~min}$. M: DNA ladder marker.

\subsection{Development of $B C_{3} F_{4}$ Pyramided Lines Using Marker-Assisted Breeding}

The $\mathrm{BC}_{2} \mathrm{~F}_{3}$ pyramided rice genotypes were evaluated for their resistance to $\mathrm{BB}$ in the field conditions using the Taiwanese Xanthomonase oryzae strain isolate, XF89-b. The resistance donor IRBB66, containing five BB resistance genes, showed shorter lesion lengths (mean lesion length of $0.43 \mathrm{~cm}$ ), while the susceptible checks, TN1, TCS10, IR24 and TNG82, exhibited a range of longer lesion lengths, between 6.75 and $12.56 \mathrm{~cm}$ (Table 1, Figure 4). The genotypes having either BB resistance genes alone or more than two genes pyramided were shown to be moderately resistant, resistant, and highly resistant to the $\mathrm{BB}$ disease (Figure 5). In addition, the five-gene-pyramided $\mathrm{BC}_{2} \mathrm{~F}_{3}$ genotypes exhibited a range of shorter lesion lengths, between 0.37 and $0.46 \mathrm{~cm}$ (Table 1). The five-gene-pyramided lines displayed higher levels of disease resistance and a broader resistance spectrum compared to both the parental rice variety, TNG82 and the genotypes possessing a single gene.

Table 1. The results of TNG82/IRBB66 $\mathrm{BC}_{2} \mathrm{~F}_{3}$ lines after incubating the Xoo strains XF89-b in the field at the first crop season in 2016.

\begin{tabular}{|c|c|c|c|c|}
\hline No. & Lines & Genotypes & Lesion Length ${ }^{\dagger}(\mathrm{cm})$ & Resistance Scale ${ }^{\ddagger}$ \\
\hline 1 & TN1 & & $12.56 \pm 2.98^{a}$ & $S$ \\
\hline 2 & TCS10 & & $9.85 \pm 2.07^{b}$ & MS \\
\hline 3 & IR24 & & $11.75 \pm 1.80^{\mathrm{a}}$ & $S$ \\
\hline 4 & TNG82 & & $6.75 \pm 2.54^{\mathrm{c}, \mathrm{d}}$ & MS \\
\hline 5 & IRBB66 & $X a 4+x a 5+X a 7+x a 13+X a 21$ & $0.43 \pm 0.70^{\mathrm{i}}$ & HR \\
\hline 6 & CNYBB0R01 & Without resistance gene & $7.30 \pm 1.50^{\mathrm{d}}$ & MS \\
\hline 7 & CNYBB0R02 & Without resistance gene & $5.91 \pm 2.04^{c}$ & MR \\
\hline 8 & CNYBB1R01 & $\mathrm{X} a 4$ & $2.67 \pm 1.00^{\mathrm{e}, \mathrm{f}}$ & $\mathrm{R}$ \\
\hline
\end{tabular}


Table 1. Cont.

\begin{tabular}{|c|c|c|c|c|}
\hline No. & Lines & Genotypes & Lesion Length ${ }^{+}(\mathrm{cm})$ & Resistance Scale ${ }^{¥}$ \\
\hline 9 & CNYBB1R02 & $x a 5$ & $2.27 \pm 0.73^{\mathrm{e}, \mathrm{f}, \mathrm{g}}$ & $\mathrm{R}$ \\
\hline 10 & CNYBB1R03 & $\mathrm{Xa7}$ & $2.77 \pm 1.04^{\mathrm{e}, \mathrm{f}}$ & $\mathrm{R}$ \\
\hline 11 & CNYBB1R04 & $x a 13$ & $5.55 \pm 2.28^{d}$ & MR \\
\hline 12 & CNYBB1R05 & $X a 21$ & $1.48 \pm 1.48^{\mathrm{f}, \mathrm{g}, \mathrm{h}, \mathrm{i}}$ & $\mathrm{R}$ \\
\hline 13 & CNYBB2R03 & $x a 13+X a 21$ & $0.77 \pm 0.45^{h, i}$ & HR \\
\hline 14 & CNYBB2R04 & $X a 4+X a 21$ & $0.68 \pm 0.24^{h, i}$ & HR \\
\hline 15 & CNYBB2R05 & $X a 4+x a 5$ & $1.24 \pm 0.98^{\mathrm{g}, \mathrm{h}, \mathrm{i}}$ & $\mathrm{R}$ \\
\hline 16 & CNYBB2R06 & $x a 5+x a 13$ & $1.82 \pm 0.54 \mathrm{f}, \mathrm{g}, \mathrm{h}$ & $\mathrm{R}$ \\
\hline 17 & CNYBB2R01 & $x a 5+X a 7$ & $0.75 \pm 0.33^{h, i}$ & HR \\
\hline 18 & CNYBB2R07 & $X a 7+x a 13$ & $3.25 \pm 0.73^{e}$ & MR \\
\hline 19 & CNYBB2R02 & $X a 7+X a 21$ & $0.76 \pm 0.19^{h, i}$ & $\mathrm{HR}$ \\
\hline 20 & CNYBB3R03 & $X a 4+x a 13+X a 21$ & $0.45 \pm 0.17^{h, i}$ & HR \\
\hline 21 & CNYBB3R04 & $X a 4+x a 5+x a 13$ & $1.25 \pm 0.74 \mathrm{~g}, \mathrm{~h}, \mathrm{i}$ & $\mathrm{R}$ \\
\hline 22 & CNYBB3R05 & $X a 4+x a 5+X a 21$ & $0.46 \pm 0.17^{h, i}$ & HR \\
\hline 23 & CNYBB3R01 & $X a 4+X a 7+X a 21$ & $0.56 \pm 0.16^{h, i}$ & $\mathrm{HR}$ \\
\hline 24 & CNYBB3R06 & $x a 5+x a 13+X a 21$ & $0.44 \pm 0.08^{h, i}$ & $\mathrm{HR}$ \\
\hline 25 & CNYBB3R07 & $x a 5+X a 7+x a 13$ & $0.71 \pm 0.45^{\mathrm{h}, \mathrm{i}}$ & $\mathrm{HR}$ \\
\hline 26 & CNYBB3R02 & $x a 5+X a 7+X a 21$ & $0.44 \pm 0.12^{h, i}$ & HR \\
\hline 27 & CNYBB4R03 & $X a 4+x a 5+x a 13+X a 21$ & $0.43 \pm 0.12^{\mathrm{i}}$ & HR \\
\hline 28 & CNYBB4R01 & $X a 4+x a 5+X a 7+X a 21$ & $0.48 \pm 0.17^{\mathrm{h}, \mathrm{i}}$ & HR \\
\hline 29 & CNYBB4R02 & $X a 4+X a 7+x a 13+X a 21$ & $0.68 \pm 0.50 \mathrm{~h}, \mathrm{i}$ & HR \\
\hline 30 & CNYBB5R01 & $X a 4+x a 5+X a 7+x a 13+X a 21$ & $0.37 \pm 0.13^{\mathrm{i}}$ & HR \\
\hline 31 & CNYBB5R02 & $X a 4+x a 5+X a 7+x a 13+X a 21$ & $0.38 \pm 0.12^{\mathrm{i}}$ & $\mathrm{HR}$ \\
\hline 32 & CNYBB5R03 & $X a 4+x a 5+X a 7+x a 13+X a 21$ & $0.46 \pm 0.14^{h, i}$ & HR \\
\hline 33 & CNYBB5R04 & $X a 4+x a 5+X a 7+x a 13+X a 21$ & $0.38 \pm 0.12^{\mathrm{i}}$ & $\mathrm{HR}$ \\
\hline
\end{tabular}

${ }^{\dagger}$ Mean \pm standard error. ${ }^{¥} \mathrm{HR}=$ highly resistant (lesion length $\left.<1 \mathrm{~cm}\right) ; \mathrm{R}=$ resistant $(1 \mathrm{~cm}<$ lesion length $<3 \mathrm{~cm})$; $\mathrm{MR}=$ moderately resistant $(3 \mathrm{~cm}<$ lesion length $<6 \mathrm{~cm}) ;$ MS = moderately susceptible $(6 \mathrm{~cm}<$ lesion length $<$ $10 \mathrm{~cm}) ; \mathrm{S}=$ susceptible $(10 \mathrm{~cm}<$ lesion length). Means with none or the same letter of a row are not significantly different at $5 \%$ level by least significant difference (LSD) test.

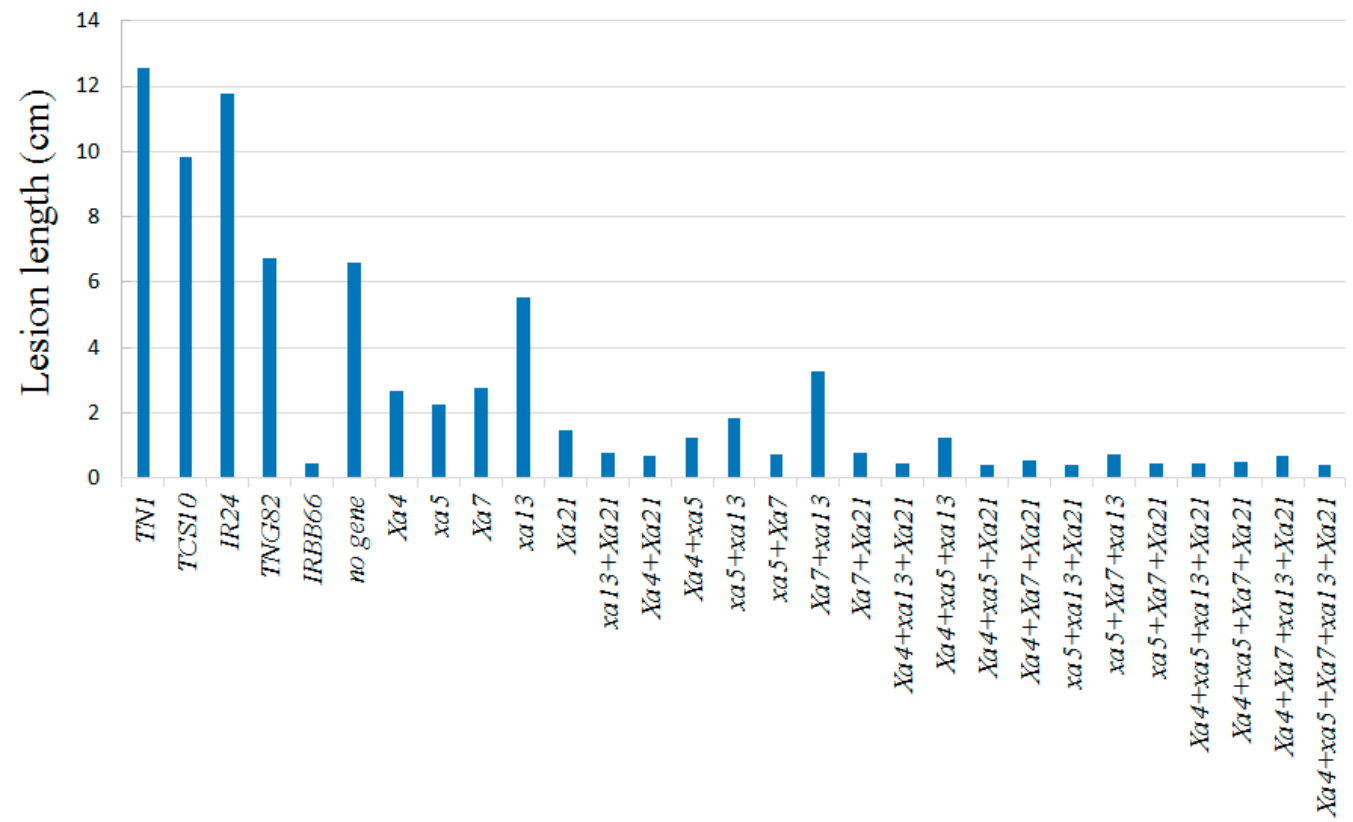

Controls and $\mathrm{BC}_{2} \mathrm{~F}_{3}$ lines

Figure 4. The leaf lesion length of TNG82/IRBB66 $\mathrm{BC}_{2} \mathrm{~F}_{3}$ genotypes after 21 days inoculum of bacterial blight pathogen XF89-b in the field at the first crop season in 2016. Susceptible cultivar: TCS10, IR24, and TN1; Parental: TNG82 and IRBB66. 


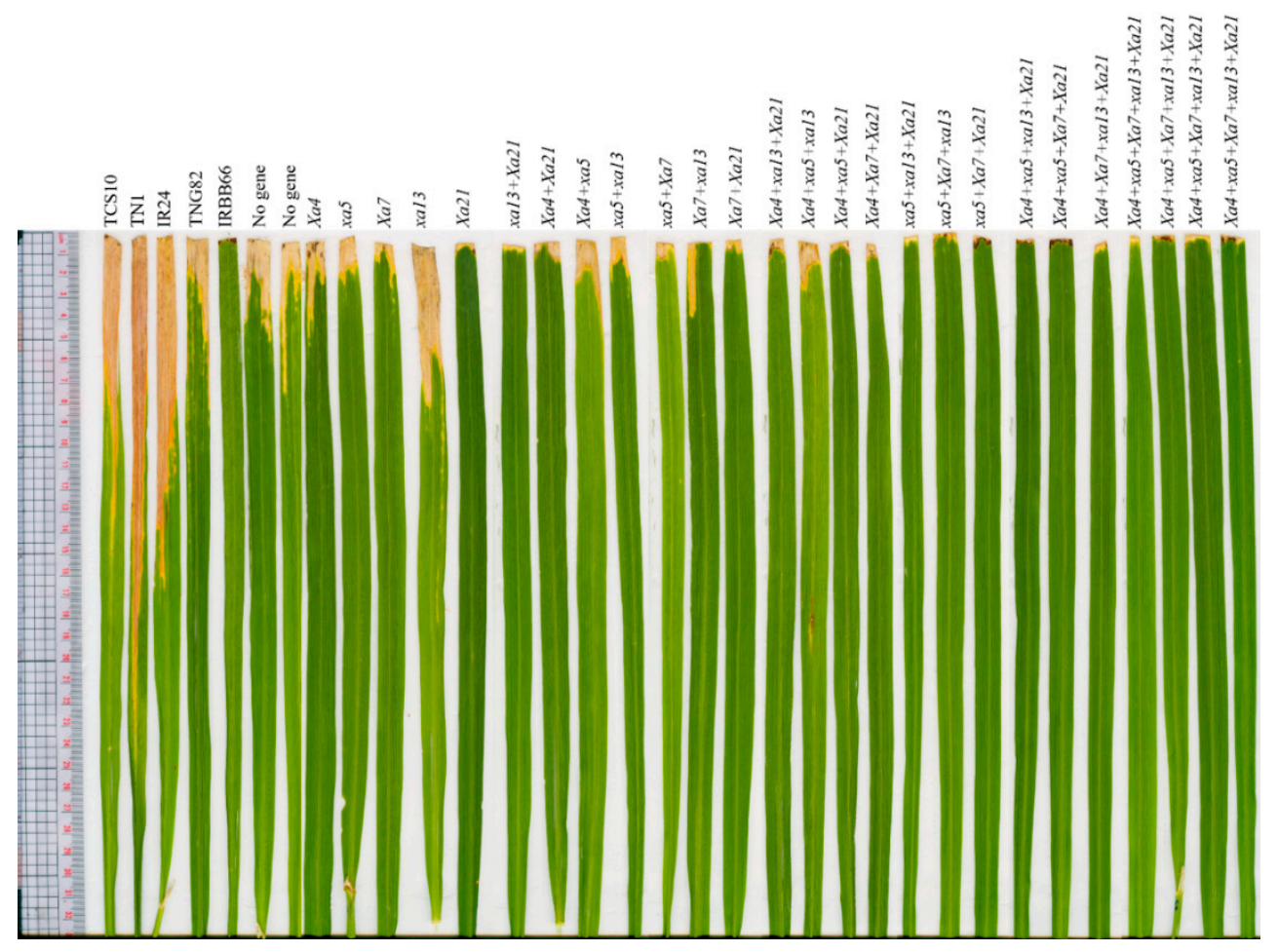

Figure 5. The leaf lesion photo of TNG82/IRBB66 $\mathrm{BC}_{2} \mathrm{~F}_{3}$ genotypes after 21 days inoculum of bacterial blight pathogen XF89-b in the field at the first crop season in 2016. Susceptible cultivar check: TCS10, IR24, and TN1; Parents: TNG82 and IRBB66.

\subsection{Development of $B C_{3} F_{4}$ Pyramided Lines Using Marker-Assisted Breeding}

Nine five-gene-pyramided lines at the $\mathrm{BC}_{3} \mathrm{~F}_{4}$ generation, along with the recurrent and donor parents, were evaluated in the first crop season of 2018 at Taiwan Agricultural Research Institute (TARI), Taiwan. Significant variances were observed between the pyramided lines and parental rice genotypes for plant height, days to $50 \%$ flowering, panicle length, panicles/plant, panicle weight, number of grains/panicle, 1000-seed weight, and single plant yield (Table 2). The recurrent parent, TNG82, recorded mean grain yield of $36.8 \mathrm{~g} /$ plant, while the donor parent, IRBB66, was $30.1 \mathrm{~g} /$ plant. Six of the nine five-gene-pyramided lines, CNYBB5R4-275, -276, -278, -279, -285 and -287, produced significantly higher grain yields per plant than the recurrent parent, which ranged from 37.1 to $44.5 \mathrm{~g} /$ plant, and displayed a similar phenotype to the donor parent TNG82 (Figure 6).

Table 2. Agro-morphologic traits of parental and five-gene-pyramided $\mathrm{BC}_{3} \mathrm{~F}_{4}$ genotypes.

\begin{tabular}{|c|c|c|c|c|c|c|c|c|}
\hline $\begin{array}{l}\text { Pyramided } \\
\text { Lines }\end{array}$ & $\begin{array}{l}\text { Plant Height } \\
(\mathrm{cm})(n=20)\end{array}$ & $\begin{array}{l}\text { Days to } 50 \% \\
\text { Flowering } \\
(n=20)\end{array}$ & $\begin{array}{c}\text { Panicle } \\
\text { Length }(\mathrm{cm}) \\
(n=20)\end{array}$ & $\begin{array}{c}\text { Panicles/Plant } \\
\quad(n=20)\end{array}$ & $\begin{array}{l}\text { Panicle } \\
\text { Weight }(\mathrm{g}) \\
(n=20)\end{array}$ & $\begin{array}{c}\text { No. of } \\
\text { Grains/Panicle } \\
(n=20)\end{array}$ & $\begin{array}{l}\text { 1000-Seed } \\
\text { Weight }(\mathrm{g}) \\
(n=20)\end{array}$ & $\begin{array}{l}\text { Single Plant } \\
\text { Yield (g) } \\
(n=20)\end{array}$ \\
\hline TNG82 & $105.4 \pm 1.1$ & 90 & $20.3 \pm 0.2$ & $14 \pm 0.7$ & $3.3 \pm 0.1$ & $102 \pm 2.5$ & $30.8 \pm 0.1$ & $36.8 \pm 0.1$ \\
\hline IRBB66 & $90.2 \pm 1.4$ & 95 & $22.6 \pm 0.1$ & $17 \pm 0.5$ & $3.7 \pm 0.1$ & $108 \pm 1.0$ & $24.2 \pm 0.1$ & $30.1 \pm 0.7$ \\
\hline CNYBB5R4-272 & $120.4 \pm 1.3$ & 92 & $22.8 \pm 1.8$ & $16 \pm 0.8$ & $3.6 \pm 0.4$ & $122 \pm 16.7$ & $26.0 \pm 0.1$ & $36.3 \pm 7.3$ \\
\hline CNYBB5R4-274 & $115.9 \pm 2.7$ & 91 & $21.4 \pm 1.6$ & $15 \pm 0.5$ & $2.8 \pm 0.1$ & $95 \pm 8.2$ & $28.4 \pm 0.4$ & $32.6 \pm 4.4$ \\
\hline CNYBB5R4-275 & $116.3 \pm 3.7$ & 91 & $20.1 \pm 0.6$ & $16 \pm 2.1$ & $3.2 \pm 0.3$ & $113 \pm 17.8$ & $25.2 \pm 0.4$ & $41.2 \pm 3.3$ \\
\hline CNYBB5R4-276 & $116.3 \pm 3.2$ & 91 & $20.4 \pm 0.7$ & $16 \pm 0.5$ & $2.8 \pm 0.2$ & $100 \pm 9.9$ & $26.4 \pm 0.4$ & $43.7 \pm 0.9$ \\
\hline CNYBB5R4-278 & $115.8 \pm 2.4$ & 91 & $21.7 \pm 0.2$ & $12 \pm 0.8$ & $3.9 \pm 0.3$ & $135 \pm 10.3$ & $26.2 \pm 0.1$ & $44.5 \pm 1.3$ \\
\hline CNYBB5R4-279 & $112.7 \pm 4.2$ & 91 & $18.3 \pm 0.1$ & $15 \pm 1.7$ & $3.1 \pm 0.1$ & $120 \pm 4.7$ & $25.2 \pm 0.2$ & $39.2 \pm 3.0$ \\
\hline CNYBB5R4-285 & $121.8 \pm 3.0$ & 92 & $21.6 \pm 0.1$ & $14 \pm 0.8$ & $3.1 \pm 0.1$ & $106 \pm 0.8$ & $28.2 \pm 0.2$ & $38.0 \pm 0.3$ \\
\hline CNYBB5R4-286 & $113.7 \pm 6.8$ & 91 & $20.2 \pm 1.0$ & $15 \pm 1.0$ & $2.9 \pm 0.2$ & $100 \pm 12.1$ & $27.6 \pm 0.1$ & $35.9 \pm 2.6$ \\
\hline CNYBB5R4-287 & $115.3 \pm 6.6$ & 91 & $21.7 \pm 0.6$ & $14 \pm 0.2$ & $2.8 \pm 0.4$ & $103 \pm 16.5$ & $26.6 \pm 1.6$ & $37.1 \pm 8.1$ \\
\hline $\operatorname{LSD}(p=0.05)$ & 9.2 & 0.6 & 2.6 & 3.1 & 0.7 & 24.0 & 1.7 & 12.1 \\
\hline
\end{tabular}

LSD, least significant difference at $5 \%$ probability level. 

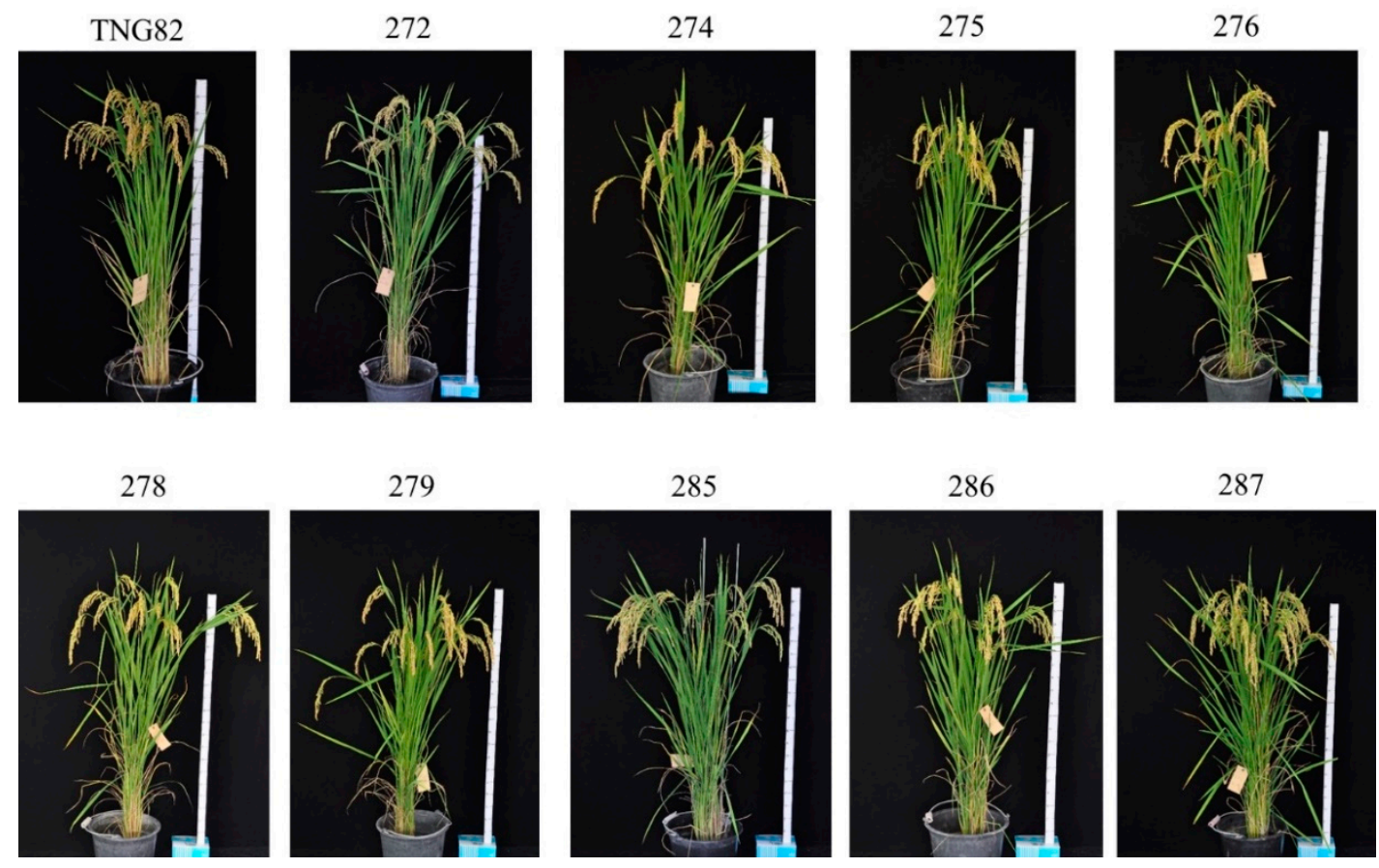

Figure 6. Phenotype of the five-gene-pyramided $\mathrm{BC}_{3} \mathrm{~F}_{4}$ genotypes compared with recurrent parental variety TNG82.

A significant difference was noted between the parental rice varieties and pyramided genotypes in grain quality traits (Table 3). The palatability among pyramided $\mathrm{BC}_{3} \mathrm{~F}_{4}$ genotypes varied between 69.8 (CNYBB5R4-275) and 74.5 (CNYBB5R4-276). The protein content among pyramided $\mathrm{BC}_{3} \mathrm{~F}_{4}$ genotypes varied between 6.4 (CNYBB5R4-276 and CNYBB5R4-286) and 7.4 (CNYBB5R4-272). The brown rice ratio for the five-gene-pyramided genotypes varied from $72.8 \%$ to $79.3 \%$. The four genotypes, CNYBB5R4-272, -275, -276 and -278, were found to have higher head rice ratios, however, the amount of total milled rice was not significantly different from the recurrent parent, TNG82. The evaluation of agronomic traits in $\mathrm{BC}_{3} \mathrm{~F}_{3}$ and $\mathrm{BC}_{3} \mathrm{~F}_{4}$ provided us with an important selection criteria, which can select candidate lines with stable agronomic performances and resistance to disease.

Table 3. Grain quality of parental and five-gene-pyramided $\mathrm{BC}_{3} \mathrm{~F}_{4}$ genotypes.

\begin{tabular}{ccccccc}
\hline Pyramided Lines & $\begin{array}{c}\text { Palatability } \\
(\boldsymbol{n}=\mathbf{2 0})\end{array}$ & Protein $(\boldsymbol{n}=\mathbf{2 0 )}$ & $\begin{array}{c}\text { Amylose } \\
(\boldsymbol{n}=\mathbf{2 0})\end{array}$ & $\begin{array}{c}\text { Brown Rice } \\
(\mathbf{\%})(\boldsymbol{n}=\mathbf{2 0})\end{array}$ & $\begin{array}{c}\text { Head Rice } \\
(\mathbf{\%})(\boldsymbol{n}=\mathbf{2 0})\end{array}$ & $\begin{array}{c}\text { Total Milled Rice } \\
(\mathbf{\%})(\boldsymbol{n}=\mathbf{2 0})\end{array}$ \\
\hline TNG82 & $76.3 \pm 3.2$ & $6.0 \pm 0.5$ & $16.0 \pm 0.1$ & $77.6 \pm 0.2$ & $55.0 \pm 0.1$ & $61.5 \pm 0.7$ \\
IRBB66 & $60.3 \pm 1.1$ & $8.7 \pm 0.3$ & $18.1 \pm 0.1$ & $72.3 \pm 0.1$ & $42.3 \pm 0.1$ & $45.7 \pm 0.4$ \\
CNYBB5R4-272 & $69.0 \pm 2.1$ & $7.4 \pm 0.4$ & $14.5 \pm 0.9$ & $74.1 \pm 0.5$ & $50.5 \pm 0.7$ & $57.8 \pm 0.8$ \\
CNYBB5R4-274 & $70.0 \pm 3.5$ & $7.3 \pm 0.7$ & $15.3 \pm 0.2$ & $72.8 \pm 0.6$ & $31.2 \pm 1.8$ & $48.6 \pm 0.1$ \\
CNYBB5R4-275 & $69.8 \pm 1.1$ & $7.2 \pm 0.2$ & $16.0 \pm 0.4$ & $75.1 \pm 2.3$ & $53.8 \pm 1.5$ & $58.7 \pm 1.3$ \\
CNYBB5R4-276 & $74.5 \pm 2.8$ & $6.4 \pm 0.5$ & $15.4 \pm 0.1$ & $77.2 \pm 0.9$ & $50.1 \pm 2.4$ & $59.0 \pm 1.0$ \\
CNYBB5R4-278 & $72.3 \pm 1.8$ & $6.7 \pm 0.3$ & $15.6 \pm 0.2$ & $77.5 \pm 0.7$ & $55.8 \pm 0.3$ & $62.1 \pm 0.1$ \\
CNYBB5R4-279 & $72.3 \pm 0.4$ & $6.8 \pm 0.1$ & $15.3 \pm 0.2$ & $77.2 \pm 1.8$ & $49.3 \pm 2.6$ & $58.1 \pm 3.6$ \\
CNYBB5R4-285 & $72.0 \pm 1.4$ & $7.0 \pm 0.7$ & $15.2 \pm 0.1$ & $77.0 \pm 1.4$ & $37.0 \pm 1.9$ & $54.4 \pm 2.2$ \\
CNYBB5R4-286 & $74.3 \pm 1.4$ & $6.4 \pm 0.3$ & $15.3 \pm 0.2$ & $79.3 \pm 0.5$ & $48.4 \pm 2.4$ & $61.2 \pm 0.1$ \\
CNYBB5R4-287 & $74.3 \pm 0.4$ & $6.8 \pm 0.1$ & $15.4 \pm 0.1$ & $75.5 \pm 0.5$ & $42.0 \pm 9.0$ & $54.7 \pm 0.6$ \\
LSD $(p=0.05)$ & 4.6 & 0.9 & 1.0 & 3.5 & 9.8 & 4.5 \\
\hline
\end{tabular}

LSD, least significant difference at $5 \%$ probability level.

\section{Discussion}

Conventional backcross breeding is the primary method used to develop highly BB-resistant rice cultivars, but it cannot accurately transfer multiple genes into the cultivar by phenotypic screening and the process requires a significant amount of time [21,22]. Modified backcross pyramid breeding, 
combined with molecular marker-assisted selection, has already been demonstrated to increase the precision and efficiency of breeding [23-25]. Due to the relatively large amount of work involved with the MAS process, the conventional backcross breeding approach has been widely adopted in breeding programs designed to breed for BB resistance [10,26-28].

To date, many rice cultivars with broad-spectrum resistance against Xoo isolates have been developed; Singh et al. (2001) pyramided three R genes, $x a 5$, Xa13 and Xa21, in the indica rice cultivars PR106 and Jalmagna using MAS to enhance the bacterial blight resistance [6,15]; the four genes Xa4, $x a 5$, $\mathrm{X} a 13$ and Xa21 were introgressed into the recurrent parent lines Jyothi, IR50, Mahsuri, PRR78, KMR3 and Pusa 6B [26,29,30]; different BB-resistant genes, Xa7, Xa21, Xa22 and Xa23, were also transferred to an elite hybrid rice restorer line, Huahui 1035, in order to improve BB resistance and enhance rice yield [31].

In Taiwan, many japonica rice cultivars lack BB resistance, resulting in significant yield loss in severely infected fields. One such variety is Tainung82, which was released in Taiwan for commercial cultivation in 2006. TNG82 is described as a popular japonica rice variety, with high-yield potential (6-7 t/ha), excellent grain quality, various culinary applications, and relatively low grain protein content $(4.5 \%-5.5 \%)$. As an extremely valuable yet BB-susceptible variety, TNG82 was selected as the focus of this study to increase BB resistance through the introgression of five BB-resistant genes, Xa4, $x a 5, \mathrm{X} a 7$, $x a 13$ and $X a 21$.

The primary purpose of backcross breeding is to transfer one or multiple genes of interest, linked to desirable traits, from donor parents into a base variety for improvement, a process which typically requires six to eight backcrosses to recover the recurrent parent's phenotype [32]. However, in the MAS scheme, three to four generations of backcrossing is generally enough to achieve more than $99 \%$ of the recurrent parent genome [33]. The theoretical \%RPG of each generation, $\mathrm{BC}_{1}, \mathrm{BC}_{2}, \mathrm{BC}_{3}$ and $\mathrm{BC}_{4}$, were $75 \%, 87.5 \%, 93.8 \%$ and $96.9 \%$, respectively. Furthermore, the \%RPG can be improved by using MAS for background selection [16,34]. The $80 \%$ and $89 \%$ recovery rates following two and three backcrosses were obtained from three-BB-gene-pyramided $\mathrm{BC}_{2}$ and $\mathrm{BC}_{3}$ genotypes, via MAS [35]. Balachiranjeevi et al. (2015) transferred the BB gene, Xa21 and rice blast-resistant gene, $P i 54$, to DRR17A and were able to recover $73.4 \%, 84.8 \%$ and $93.4 \% \mathrm{RPG}$ in the $\mathrm{BC}_{1}, \mathrm{BC}_{2}$ and $\mathrm{BC}_{3}$ generations, respectively.

In this study, the recurrent parent genome recovery rates in $\mathrm{BC}_{1} \mathrm{~F}_{1}, \mathrm{BC}_{2} \mathrm{~F}_{1}$ and $\mathrm{BC}_{2} \mathrm{~F}_{2}$ were $73.8 \%, 83 \%$ and $84.7 \%$ (Figure 2), respectively. Compared with the theoretical \%RPG, a relatively low background recovery rate was obtained, however, the results were consistent with those found in previous studies [36,37]. Marker-assisted backcrossing can accelerate the breeding process and facilitate a speedy recovery for most of the recurrent genome within a few generations [38], however, the population size of each backcross generation, linkage drag, number of background markers used and genetic background between two parents are considered to be factors that reduce the efficiency of MAB and \%RPG [32].

Bacterial blight is one of the most destructive diseases affecting rice productivity in Asia. In Taiwan, rice production is frequently affected by $B B$ in the second crop season, resulting in substantial yield loss. In recent years, BB has become a more prevalent threat, due to climate change [39]. XF89-b, a strong and stable Taiwanese epidemic pathogen, has also been used for genetic analysis and the mapping of BB-related resistance genes [40]. In our bioassays, artificial screening of $\mathrm{BC}_{2} \mathrm{~F}_{3}$ progenies revealed that all genotypes containing at least one $\mathrm{BB}$-resistant gene displayed a degree of increased resistance (Table 1, Figure 4). The $\mathrm{BC}_{2} \mathrm{~F}_{3}$ progenies that pyramided more than three BB-resistant genes exhibited a very high level of BB resistance against the XF89-b strain, compared to parental lines (Figure 5). The lesion lengths were measured between 0.37 and $1.25 \mathrm{~cm}$ (Table 1). The data indicated that multiple BB-resistant genes pyramided in rice can improve resistance to Xoo. The BB pyramiding lines are expected to enhance the adaptability and durability necessary to provide resistance against the dynamic nature of the pathogen. In addition, the results suggest that the gene combinations containing the $\mathrm{X} a 21$ gene were most resistant, as evidenced by shorter lesions lengths, followed by $X a 4+X a 21, X a 7+X a 21$ and $x a 13+X a 21$, while lines with $X a 4+x a 5, x a 5+x a 13$ and $X a 7+x a 13$ were 
less effective. These results are consistent with previous studies, which have shown the presence of $X a 21$ to be correlated with high levels of persistent resistance against BB disease in rice $[6,14,15,17,25]$. $\mathrm{X} a 21$ is the cell surface receptor, kinase, which is able to provide resistance to Xoo infections; Xa21 not only suppresses Xoo growth, but also triggers broad perturbation in rice transcriptomes and mediated signaling pathways, preventing Xoo infections [14].

The agronomic performance evaluation of $\mathrm{BC}_{3} \mathrm{~F}_{4}$ derived in the genetic background of TNG82 revealed that all pyramided lines for most of the agro-morphological traits were, in general, similar to the recipient parent, TNG82. However, six candidate lines, CNYBB5R4-275, -276, -278, -279, -285 and -287 , produced significantly higher grain yields per plant than the recurrent parent, which was further confirmed by the multilocation evaluation. In addition, three candidate lines, CNYBB5R4-276, -278 and -286, were not significantly different in palatability, protein, amylose, brown rice ratio, head rice ratio or total milled rice ratio, indicating that the $\mathrm{BC}_{3} \mathrm{~F}_{4}$ pyramiding lines had grain quality consistent with TNG82. The data showed that there were no yield or grain quality reductions, but rather improvements, due to the pyramiding of the five BB-resistant genes.

\section{Materials and Methods}

\subsection{Plant Materials}

The donor parent, IRBB66, contained five resistance genes, Xa4, $x a 5, X a 7, x a 13$ and Xa21, which were introgressed from wild species in the background of IR24. IRBB66 was provided as a courtesy by the Genetic Resources Center (GRC) of the International Rice Research Institute (IRRI). The recurrent parent was TNG82, an elite japonica cultivar with low protein content and good grain quality, but susceptible to bacterial blight disease. A cross was made between TNG82 and IRBB66, with $\mathrm{F}_{1}$ plants backcrossed thrice with TNG82 to obtain $\mathrm{BC}_{3} \mathrm{~F}_{1}$ plants, which were selfed to obtain the $\mathrm{BC}_{3} \mathrm{~F}_{4}$ progeny. Selection based on foreground, background and agronomic traits were practiced from $\mathrm{BC}_{1} \mathrm{~F}_{1}$ to $\mathrm{BC}_{2} \mathrm{~F}_{2}$ as a means of identifying lines similar to the recurrent parent.

\subsection{Evaluation of Bacterial Blight Resistance}

The parental varieties (IRBB66 and TNG82), susceptible varieties (Taichung Native 1 (TN1), Taichung sen 10 (TCS10)), $\mathrm{BC}_{2} \mathrm{~F}_{2}$ and $\mathrm{BC}_{2} \mathrm{~F}_{3}$ generation genotypes were pyramided with the five BB-resistant genes, with IR24 as control. Different combinations were evaluated for BB resistance under greenhouse and field conditions with the pathogen, X. oryzae pv. oryzae. Pathogen inoculation was performed at the maximum tillering stage in the field through the modified leaf clipping method, as previously described [41]. A strong Taiwanese epidemic pathogen isolate, XF89-b, was used in this study. The isolate was grown in 523 medium [42] with agitation at room temperature for two days. After adjusting the optical bacterial density to $10^{9} \mathrm{CFU} / \mathrm{mL}$ with distilled water, the cultures were used to screen the rice plants for $\mathrm{BB}$ resistance. Approximately six leaves from one plant were clipped from the top $2-3 \mathrm{~cm}$ simultaneously. All inoculation was completed within $1 \mathrm{~h}$ following the preparation of bacterial suspensions. Lesion length for BB was scored after inoculation when the lesion of the susceptible variety, TN1, reached approximately $3 / 4$ of overall leaf length (approximately 21-28 days). The resistance reaction was classified as highly resistant (HR), resistant (R), moderately resistant (MR), moderately susceptible (MS), and susceptible (S) when the values of lesion length were recorded as $0-1 \mathrm{~cm}, 1.1-3 \mathrm{~cm}, 3.1-6 \mathrm{~cm}, 6.1-10 \mathrm{~cm}$, and more than $10 \mathrm{~cm}$, respectively [43,44].

\subsection{Evaluation of Agronomic Traits}

During the second and first crop season of 2017 and 2018, respectively, the 30-day-old seedlings of the $\mathrm{BC}_{3} \mathrm{~F}_{3}$ and $\mathrm{BC}_{3} \mathrm{~F}_{4}$ pyramided lines and both the parents were transplanted into three rows, with 27 plants per row, per entry, at $15 \times 25 \mathrm{~cm}$ spacing, under a randomized complete-block design, with two replications at the Taiwan Agricultural Research Institute's Chiayi Agricultural Experiment Station Farm. Ten plants from each entry were recorded as one data replication. Single plant yield 
was recorded for the $16 \mathrm{BC}_{3} \mathrm{~F}_{3}$ genotypes as a basis for selection. In $\mathrm{BC}_{3} \mathrm{~F}_{4}$, variables for agronomic traits were recorded for nine pyramided lines, including: plant height $(\mathrm{cm})$, days to $50 \%$ flowering, panicle length $(\mathrm{cm})$, panicles/plant, panicle weight $(\mathrm{g})$, number of grains/panicle and 1000-seed weight (g), while single plant yield (g) was recorded on a whole-plot basis. In addition, the grain quality, including palatability, protein, amylose, brown rice ratio, head rice ratio and total milled rice ratio, was investigated and analyzed. For palatability analyses, the rice grains were hulled and ground into a fine flour. Approximately $33 \mathrm{~g}$ of rice flour was used for the palatability evaluation, which was performed by using a palatability analyzer system (Toyo Taste Meter, Model MA-30), in accordance with the manufacturer's operation manual (TRCM Co., Toyo Rice Polishing Machine Factory, Japan), as previously described [45]. Protein and amylose contents were measured with a near-infrared spectrometer (AN820, Kett Electric Laboratory Co. Ltd., Tokyo, Japan) (Near Infrared Spectrometer, Foss Japan Co. Ltd., Tokyo, Japan). Statistical analysis was performed with independent samples using least significant difference (LSD).

\subsection{DNA Isolation and PCR Amplification}

A rice genomic DNA extraction, with modification, was adopted for minipreparation [45]. Approximately $0.05 \mathrm{~g}$ of fresh leaf tissue from 6- to 8-week-old seedlings was homogenized with $300 \mu \mathrm{L}$ extraction buffer (100 mM Tis-HCl, pH 9.0; $40 \mathrm{mM}$ EDTA-2Na, pH 8.0; 1.67\% SDS) at 30 1/s for $2 \mathrm{~min}$ by use of TissueLyser (Qiagen Retsch $\mathrm{GmbH}$, Haan, Germany). A total of $150 \mu \mathrm{L}$ benzyl chloride was added to the homogenized tissue and vortexed. After incubation in a $50{ }^{\circ} \mathrm{C}$ water bath for $15 \mathrm{~min}$, $150 \mu \mathrm{L}$ of $3 \mathrm{M}$ sodium acetate ( $\mathrm{pH}$ 5.2) was added. Supernatants were saved after centrifugation at $15,000 \mathrm{rpm}$ for $15 \mathrm{~min}$ at $4{ }^{\circ} \mathrm{C}$, and $300 \mu \mathrm{L}$ of ice-cold isopropanol was added to precipitate DNA. After centrifugation at 15,000 rpm for $10 \mathrm{~min}$, DNA pellets were saved and washed with $70 \%$ ethanol, air-dried and dissolved in $50 \mu \mathrm{L}$ TE buffer.

A $10 \mu \mathrm{L}$ PCR reaction containing $20 \mathrm{ng}$ genomic DNA, $0.2 \mu \mathrm{M}$ forward and reverse primers, $5 \mu \mathrm{L}$ Multiplex PCR Master Mix (QIAGEN, Inc., Valencia, CA), and $1 \mu \mathrm{L}$ Q-Solution (QIAGEN, Inc., Valencia, CA) was performed by use of a thermocycler (GeneAmp PCR System 9700, PerkinElmer Corp., Norwalk, CT, USA) at $95^{\circ} \mathrm{C}$ for $15 \mathrm{~min}$ for 1 cycle; $94{ }^{\circ} \mathrm{C}$ for $30 \mathrm{~s}, 57^{\circ} \mathrm{C}$ for $2 \mathrm{~min}, 72{ }^{\circ} \mathrm{C}$ for $2 \mathrm{~min}$ for 30 cycles; and $60^{\circ} \mathrm{C}$ for $30 \mathrm{~min}$ for 1 cycle. Following PCR, $2 \mu \mathrm{L}$ of amplified DNA products was separated by $6 \%$ polyacrylamide gel (PAGE) in $0.5 \times$ TBE at $100 \mathrm{v}$ (Dual Triple-Wide Mini-Vertical System, C. B. S. Scientific, CA, USA) for $60 \mathrm{~min}$.

\subsection{Marker Analysis}

Five gene-specific primers, Xa4F/4R, RM604F/604R, Xa7F/7-1R/7-2R, Xa13F/13R, and Xa21F/21R, tightly linked to the resistance genes $\mathrm{X} a 4, x a 5, \mathrm{X} a 7, x a 13$ and $\mathrm{X} a 21$, respectively, were used to confirm the presence of the $\mathrm{R}$ genes in each generation. All markers in this study were published in the previous report [10]. In addition, a total of 36 and 44 markers of known chromosomal positions were used for genotyping in $\mathrm{BC}_{1} \mathrm{~F}_{1}$ and $\mathrm{BC}_{2} \mathrm{~F}_{1}$, respectively. In $\mathrm{BC}_{2} \mathrm{~F}_{2}, 117$ markers, including $57 \mathrm{SSRs}$, 9 STS, and 51 InDel, distributed evenly on the 12 chromosomes with an average marker interval of $12.76 \mathrm{cM}$, were used in a genome-wide survey to identify the chromosome segment substitution locations. These polymorphic markers were used for background selection in order to select plants having maximum recovery of the recurrent parent genome. The genotypes from polymorphic bands are recorded as A (IRBB66), B (TNG82) and H (IRBB66/TNG82). The Graphical Geno Types (GGT) Version 2.0 [46] software program was used for the assessment of the recurrent parent genome (\%RPG) in the selected recombinants, based on marker data.

\section{Conclusions}

The use of marker-assisted selection in backcross breeding is an effective and reliable approach for pyramiding BB-resistant genes in rice. In this study, the pyramiding lines that possess resistance against BB strains, high potential yields, and high grain quality were both developed and improved. 
The BB-pyramided breeding lines containing all five genes, $\mathrm{X} a 4, x a 5, \mathrm{X} a 7, x a 13$ and $\mathrm{X} a 21$, can serve as donors to introgress the resistance genes into other elite rice cultivars in order to accelerate the improvement of rice for disease resistance in Taiwan. These BB-pyramided lines are expected to have a high impact on domestic rice production stability, and also reduce the need for pesticides.

Supplementary Materials: The following are available online at http:/www.mdpi.com/1422-0067/21/4/1281/s1. Figure S1: The polymorphic markers used for background selection of TNG82/IRBB66 backcross population. Table S1: The genome composition of $\mathrm{BC}_{2} \mathrm{~F}_{2}$ derived from TNG82/IRBB66 by 117 polymorphic markers used for MAS.

Author Contributions: Conceptualization, Y.-C.H. and Y.-P.W.; methodology, Y.-P.W.; validation, Y.-P.W.; formal analysis, C.-H.C.; investigation, Y.-C.H., C.-H.C., R.Y., and Y.-P.W.; data curation, Y.-C.H. and R.Y.; writing - original draft preparation, Y.-C.H.; writing-review and editing, Y.-C.T. and Y.-P.W.; supervision, Y.-C.H. and Y.-P.W. All authors have read and agreed to the published version of the manuscript.

Funding: This work was supported by the Ministry of Science and Technology (MOST 108-2313-B-415-007) of Taiwan. We are grateful to National Plant Resources Center for providing the rice materials.

Acknowledgments: The authors are highly grateful to the technical support from Plant Protection Division, Chiayi Agricultural Experiment Station, Taiwan Agricultural Research Institute.

Conflicts of Interest: The authors declare that they have no conflict of interests.

\section{References}

1. FAO. Global Agriculture Towards 2050; FAO: Rome, Italy, 2009.

2. Ray, D.K.; Mueller, N.D.; West, P.C.; Foley, J.A. Yield trends are insufficient to double global crop production by 2050. PLoS ONE 2013, 8, e66428. [CrossRef] [PubMed]

3. Khush, G.S.; Mackill, D.J.; Sidhu, G.S. Breeding rice for resistance to bacterial leaf blight. In IRRI Bacterial Blight of Rice; IRRI: Manila, Philippines, 1989; pp. 207-217.

4. Singh, G.P.; Singh, S.R.; Singh, R.V.; Singh, R.M. Variation and qualitative losses caused by bacterial blight in different rice varieties. Indian Phytopathol. 1997, 30, 180-185.

5. Perez, L.M.; Redoña, E.D.; Mendioro, M.S.; Vera Cruz, C.M.; Leung, H. Introgression of Xa4, Xa7 and Xa21 for resistance to bacterial blight in thermosensitive genetic male sterile rice (Oryza sativa L.) for the development of two-line hybrids. Euphytica 2008, 164, 627-636. [CrossRef]

6. Pradhan, S.K.; Nayak, D.K.; Mohanty, S.; Behera, L.; Barik, S.R.; Pandit, E.; Lenka, S.; Anandan, A. Pyramiding of three bacterial blight resistance genes for broad-spectrum resistance in deepwater rice variety, Jalmagna. Rice 2015, 8, 51. [CrossRef]

7. Prahalada, G.D.; Ramkumar, G.; Hechanova, S.L.; Vinarao, R.; Jena, K.K. Exploring key blast and bacterial blight resistance genes in genetically diverse rice accessions through molecular and phenotypic evaluation. Crop Sci. 2017, 57, 1881-1892. [CrossRef]

8. Song, W.Y.; Wang, G.L.; Chen, L.L.; Kim, H.S.; Pi, L.Y.; Holsten, T.; Gardner, J.; Wang, B.; Zhai, W.X.; Zhu, L.H.; et al. A receptor kinase-like protein encoded by the rice disease resistance gene, Xa21. Science 1995, 270, 1804-1806. [CrossRef]

9. Sun, X.; Yang, Z.; Wang, S.; Zhang, Q. Identification of a 47-kb DNA fragment containingXa4, a locus for bacterial blight resistance in rice. Theor. Appl. Genet. 2003, 106, 683-687. [CrossRef]

10. Yap, R.; Hsu, Y.-C.; Wu, Y.P.; Lin, Y.R.; Kuo, C.W. Multiplex PCR genotyping for five bacterial blight resistance genes applied to marker-assisted selection in rice (Oryza sativa). Plant Breed. 2016, 135, 309-317. [CrossRef]

11. Iyer, A.S.; McCouch, S.R. The rice bacterial blight resistance gene xa5 encodes a novel form of disease resistance. Mol. Plant Microbe Interact. 2004, 17, 1348-1354. [CrossRef]

12. Wang, Y.H.; Liu, S.J.; Ji, S.L.; Zhang, W.W.; Wang, C.M.; Jiang, L.; Wan, J.M. Fine mapping and marker-assisted selection (MAS) of a low glutelin content gene in rice. Cell Res. 2005, 15, 622-630. [CrossRef]

13. Chu, Z.; Fu, B.; Yang, H.; Xu, C.; Li, Z.; Sanchez, A.; Park, Y.J.; Bennetzen, J.L.; Zhang, Q.; Wang, S. Targetingxa13, a recessive gene for bacterial blight resistance in rice. Theor. Appl. Genet. 2006, 112, 455-461. [CrossRef] [PubMed]

14. Peng, H.; Chen, Z.; Fang, Z.; Zhou, J.; Xia, Z.; Gao, L.; Chen, L.; Li, L.; Li, T.; Zhai, W.; et al. Rice Xa21 primed genes and pathways that are critical for combating bacterial blight infection. Sci. Rep. 2015, 5, 12165. [CrossRef] [PubMed] 
15. Singh, S.; Sidhu, J.S.; Huang, N.; Vikal, Y.; Li, Z.; Brar, D.S.; Dhaliwal, H.S.; Khush, G.S. Pyramiding three bacterial blight resistance genes (Xa5, Xa13 and Xa21) using marker-assisted selection into indica rice cultivar PR106. Theor. Appl. Genet. 2001, 102, 1011-1015. [CrossRef]

16. Suh, J.P.; Jeung, J.U.; Noh, T.H.; Cho, Y.C.; Park, S.H.; Park, H.S.; Shin, M.S.; Kim, C.K.; Jena, K.K. Development of breeding lines with three pyramided resistance genes that confer broad-spectrum bacterial blight resistance and their molecular analysis in rice. Rice 2013, 6, 5. [CrossRef] [PubMed]

17. Ramalingam, J.; Savitha, P.; Alagarasan, G.; Saraswathi, R.; Chandrababu, R. Functional marker assisted improvement of stable cytoplasmic male sterile lines of rice for bacterial blight resistance. Front. Plant Sci. 2017, 8, 1131. [CrossRef]

18. Ruengphayak, S.; Chaichumpoo, E.; Phromphan, S.; Kamolsukyunyong, W.; Sukhaket, W.; Phuvanartnarubal, E.; Korinsak, S.; Korinsak, S.; Vanavichit, A. Pseudo-backcrossing design for rapidly pyramiding multiple traits into a preferential rice variety. Rice 2015, 8, 7. [CrossRef]

19. Guvvala, L.; Koradi, P.; Shenoy, V.; Marella, L. Making an Indian traditional rice variety Mahsuri, bacterial blight resistant using marker-assisted selection. J. Crop Sci. Biotech. 2013, 16, 111-121. [CrossRef]

20. Huang, N.; Angeles, E.R.; Domingo, J.; Magpantay, G.; Singh, S.; Zhang, G.; Kumaravadivel, N.; Bennett, J.; Khush, G.S. Pyramiding of bacterial blight resistance genes in rice: Marker-assisted selection using RFLP and PCR. Theor. Appl. Genet. 1997, 95, 313-320. [CrossRef]

21. Crossa, J.; Perez-Rodriguez, P.; Cuevas, J.; Montesinos-Lopez, O.; Jarquin, D.; de Los Campos, G.; Burgueno, J.; Gonzalez-Camacho, J.M.; Perez-Elizalde, S.; Beyene, Y.; et al. Genomic selection in plant breeding: Methods, models, and perspectives. Trends Plant Sci. 2017, 22, 961-975. [CrossRef]

22. Mehta, S.; Singh, B.; Dhakate, P.; Rahman, M.; Islam, M.A. Rice, Marker-Assisted Breeding, and Disease Resistance. In Disease Resistance in Crop Plants: Molecular, Genetic and Genomic Perspectives; Wani, S.H., Ed.; Springer International Publishing: Cham, Switzerland, 2019; pp. 83-111.

23. Abhilash Kumar, V.; Balachiranjeevi, C.H.; Bhaskar Naik, S.; Rambabu, R.; Rekha, G.; Harika, G.; Hajira, S.K.; Pranathi, K.; Anila, M.; Kousik, M.; et al. Development of gene-pyramid lines of the elite restorer line, RPHR-1005 possessing durable bacterial blight and blast resistance. Front Plant Sci. 2016, 7, 1195. [CrossRef]

24. Abhilash Kumar, V.; Balachiranjeevi, C.H.; Bhaskar Naik, S.; Rekha, G.; Rambabu, R.; Harika, G.; Pranathi, K.; Hajira, S.K.; Anila, M.; Kousik, M.; et al. Marker-assisted pyramiding of bacterial blight and gall midge resistance genes into RPHR-1005, the restorer line of the popular rice hybrid DRRH-3. Mol. Breed. 2017, 37, 86. [CrossRef]

25. Yugander, A.; Sundaram, R.M.; Singh, K.; Senguttuvel, P.; Ladhalakshmi, D.; Kemparaju, K.B.; Madhav, M.S.; Prasad, M.S.; Hariprasad, A.S.; Laha, G.S. Improved versions of rice maintainer line, APMS 6B, possessing two resistance genes, Xa21 and Xa38, exhibit high level of resistance to bacterial blight disease. Mol. Breed. 2018, 38, 100. [CrossRef]

26. Bharathkumar, S.; Paulraj, R.S.D.; Brindha, P.V.; Kavitha, S.; Gnanamanickam, S.S. Improvement of bacterial blight resistance in rice cultivars Jyothi and IR50 via marker-assisted backcross breeding. J. Crop Improv. 2008, 21, 101-116. [CrossRef]

27. Joseph, M.; Krishnan, S.; Sharma, R.; Singh, V.P.; Singh, A.; Singh, N.; Mohapatra, T. Combining bacterial blight resistance and Basmati quality characteristics by phenotypic and molecular marker-assisted selection in rice. Molecular Breed. 2004, 13, 377-387. [CrossRef]

28. Luo, Y.; Sangha, J.S.; Wang, S.; Li, Z.; Yang, J.; Yin, Z. Marker-assisted breeding of Xa4, Xa21 and Xa27 in the restorer lines of hybrid rice for broad-spectrum and enhanced disease resistance to bacterial blight. Molecular Breed. 2012, 30, 1601-1610. [CrossRef]

29. Lalitha Devi, G.; Koradi, P.; Shenoy, V.; Shanti, L. Improvement of resistance to bacterial blight through marker assisted backcross breeding and field validation in rice (Oryza sativa). Res. J. Biol. 2013, 1, 52-66.

30. Shanti, M.L.; Shenoy, V.V.; Lalitha Devi, G.; Mohan Kumar, V.; Premalatha, P.; Naveen Kumar, G.; Shashidhar, H.E.; Zehr, U.B.; Freeman, W.H. Marker-assisted breeding for resistance to bacterial leaf blight in popular cultivar and parental lines of hybrid rice. J. Plant Pathol. 2010, 92, 495-501.

31. Huang, B.; Xu, J.Y.; Hou, M.S.; Ali, J.; Mou, T.M. Introgression of bacterial blight resistance genes Xa7, $\mathrm{X} a 21, \mathrm{X} a 22$ and Xa23 into hybrid rice restorer lines by molecular marker-assisted selection. Euphytica 2012, 187, 449-459. [CrossRef] 
32. Hasan, M.M.; Rafii, M.Y.; Ismail, M.R.; Mahmood, M.; Rahim, H.A.; Alam, M.A.; Ashkani, S.; Malek, M.A.; Latif, M.A. Marker-assisted backcrossing: A useful method for rice improvement. Biotechnol. Biotechnol. Equip. 2015, 29, 237-254. [CrossRef]

33. Jiang, G.L. Molecular Markers and Marker-Assisted Breeding in Plants. In Plant Breeding from Laboratories to Fields; Andersen, S.B., Ed.; IntechOpen: Croatia, 2013; pp. 45-83.

34. Rajpurohit, D.; Kumar, R.; Kumar, M.; Paul, P.; Awasthi, A.; Osman Basha, P.; Puri, A.; Jhang, T.; Singh, K.; Dhaliwal, H.S. Pyramiding of two bacterial blight resistance and a semidwarfing gene in Type 3 Basmati using marker-assisted selection. Euphytica 2011, 178, 111-126. [CrossRef]

35. Sundaram, R.M.; Vishnupriya, M.R.; Biradar, S.K.; Laha, G.S.; Reddy, G.A.; Rani, N.S.; Sarma, N.P.; Sonti, R.V. Marker assisted introgression of bacterial blight resistance in Samba Mahsuri, an elite indica rice variety. Euphytica 2008, 160, 411-422. [CrossRef]

36. Balachiranjeevi, C.; Bhaskar, N.S.; Abhilash, V.; Akanksha, S.; Viraktamath, B.C.; Madhav, M.S.; Hariprasad, A.S.; Laha, G.S.; Prasad, M.S.; Balachandran, S.; et al. Marker-assisted introgression of bacterial blight and blast resistance into DRR17B, an elite, fine-grain type maintainer line of rice. Mol. Breed. 2015, 35, 151. [CrossRef]

37. Singh, A.; Singh, V.K.; Singh, S.P.; Pandian, R.T.P.; Ellur, R.K.; Singh, D.; Bhowmick, P.K.; Gopala Krishnan, S.; Nagarajan, M.; Vinod, K.K.; et al. Molecular breeding for the development of multiple disease resistance in Basmati rice. AoB Plants 2012, 2012. [CrossRef] [PubMed]

38. Cobb, J.N.; Biswas, P.S.; Platten, J.D. Back to the future: Revisiting MAS as a tool for modern plant breeding. Theor. Appl. Genet. 2019, 132, 647-667. [CrossRef]

39. Tseng, H.Y.; Lin, D.G.; Hsieh, H.Y.; Tseng, Y.J.; Tseng, W.B.; Chen, C.W.; Wang, C.S. Genetic analysis and molecular mapping of QTLs associated with resistance to bacterial blight in a rice mutant, SA0423. Euphytica 2015, 205, 231-241. [CrossRef]

40. Wang, C.S.; Lin, D.G. The Application of Genomic Approaches in Studying a Bacterial Blight-Resistant Mutant in Rice. In Advances in International Rice Research; Li, J.Q., Li, J., Eds.; IntechOpen: London, UK, 2017.

41. Kauffman, H.E.; Reddy, A.P.K.; Hsieh, S.P.Y.; Merca, S.D. An improved technique for evaluating resistance of rice varieties to Xanthomonas oryzae. Plant Dis. Rep. 1973, 57, 537-541.

42. Kado, C.I.; Heskett, M.G. Selective media for isolation of Agrobacterium, Corynebacterium, Erwinia, Psedumonoas and Xanthomonas. Phytopathology 1970, 60, 969-976. [CrossRef]

43. IRRI. Standard Evaluation System; In International Rice Research Institute: Manila, Philippines, 1996; p. 52.

44. Latif, M.A.; Badsha, M.A.; Tajul, M.I.; Kabir, M.S.; Rafii, M.Y.; Mia, M.A.T. Dentification of genotypes resistant to blast, bacterial leaf blight, sheath blight and tungro and efficacy of seed treating fungicides against blast disease of rice. Sci. Res. Essays 2011, 6, 2804-2811.

45. Hsu, Y.C.; Tseng, M.C.; Wu, Y.P.; Lin, M.Y.; Wei, F.J.; Hwu, K.K.; Hsing, Y.I.; Lin, Y.R. Genetic factors responsible for eating and cooking qualities of rice grains in a recombinant inbred population of an inter-subspecific cross. Mol. Breed. 2014, 34, 655-673. [CrossRef]

46. Van Berloo, R. GGT: Software for the display of graphical genotypes. J. Hered. 1999, 90, 328-330. [CrossRef]

(C) 2020 by the authors. Licensee MDPI, Basel, Switzerland. This article is an open access article distributed under the terms and conditions of the Creative Commons Attribution (CC BY) license (http://creativecommons.org/licenses/by/4.0/). 